\title{
SIMULASI PRAKIRAAN JUMLAH CURAH HUJAN DENGAN MENGGUNAKAN DATA PARAMETER CUACA \\ (STUDY KASUS DI KOTA PEKANBARU TAHUN 2012)
}

\author{
Aristya Ardhitama \\ Stasiun Meteorologi Pekanbaru \\ ardhi_pku@yahoo.co.id
}

\begin{abstract}
INTISARI
Simulasi prakiraan jumlah curah hujan bulanan dengan menggunakan input dapat parameter cuaca di Kota Pekanbaru telah dilakukan menggunakan model persamaan regresi linear berganda. Untuk memvalidasi kebenaran hasil prakiraan jumlah curah hujan dengan model persamaan regresi linear berganda dihitung nilai Mean absolut Error (MAE) dan nilai uji t student untuk mengetahui kesamaan nilai rata-rata dari jumlah curah hujan prediksi dengan jumlah curah hujan aktualnya. Hasil pengolahan data yang telah dilakukan menunjukkan bahwa simulasi prediksi curah hujan bulanan tahun 2009 dengan menggunakan data parameter cuaca didapatkan penyimpangan nilai MAE sebesar 32.93 $\mathrm{mm} /$ bulan dan dari uji t student terbukti bahwa model regresi linear prediksi curah hujan mempunyai kesamaan dengan nilai rata-rata jumlah curah hujan bulanan aktualnya.
\end{abstract}

Kata kunci : Jumlah hujan bulanan, data parameter cuaca, regresi linear berganda

\section{PENDAHULUAN}

Kota Pekanbaru terletak antara $101^{\circ} 14^{\prime}$ 101³4' Bujur Timur dan $0^{\circ} 25^{\prime}$ - $0^{\circ} 45^{\prime}$ Lintang Utara. Dengan ketinggian dari permukaan laut berkisar antara 5 - 50 meter. Pada mulanya di Kota belum banyak terdapat bangunan. Tetapi pada awal tahun 1990-an perkembangan pembangunan di Kota Pekanbaru mulai signifikan, hal ini terjadi karena letaknya yang cukup strategis dimana Kota Pekanbaru merupakan pusat perekonomian dan ibu kota di Propinsi Riau.

Pembangunannya cukup pesat menjadikan Kota Pekanbaru salah satu kota metropolitan di Indonesia. Pembangunan dan mobilitas masyarakat Kota Pekanbaru yang semakin tinggi seperti sekarang ini membawa dampak perubahan pola cuaca yang paling signifikan adalah kenaikan suhu udara dan kasus kejadian hujan lebat yang sering terjadi. Pekanbaru terjadi diatasnya. Pola kekhasan cuaca di Pekanbaru sangat dipengaruhi oleh letak geografisnya yang terletak disekitar wilayah garis khatulistiwa sehingga memiliki tipe hujan ekuatorial yang sepanjang tahun hujan dan berada di lembah bukit barisan membuat Pekanbaru yang membentuk sirkulasi angin lembah dan angin gunung. Sirkulasi angin lembah dan angin gunung terbentuk akibat perbedaan suhu pada siang hari.

Salah satu karakteristik dari type iklim equatorial adalah curah hujan yang tinggi mencapai 2500 milimeter/tahun. dan hampir terjadi sepanjang tahun. Artinya dalam musim kemarau pun masih terdapat hujan meskipun dengan intensitas yang sedikit.
Secara umum puncak musim hujan di Riau terjadi pada bulan Maret - April dan Oktober Nopember. Artinya pada bulan - bulan tersebut daerah Pekanbaru perlu diwaspadai terjadi banjir dikarenakan adanya curah hujan yang cukup tinggi. Masalah banjir sering dikaitkan dengan keadaan curah hujan yang cukup tinggi yang terjadi setiap tahun dan menjadi masalah klasik yang terus berulang. Beberapa faktor yang menjadikan adanya kasus kejadian hujan lebat yang turun di Kota Pekanbaru adalah adanya dampak dari efek perkotaan yang terjadi, selain itu juga disebabkan oleh peristiwa pemanasan global dan perubahan iklim yang mengakibatkan kejadian cuaca ekstrim yaitu hujan lebat yang terjadi.

Dalam kajian ini berupaya membuat simulasi faktor -faktor paramater cuaca yaitu yang mempengaruhi jumlah hujan bulanan di Pekanbaru. Untuk mempersempit pokok analisisnya dalam kajian ini penulis mengambil sampel jumlah curah hujan setiap bulannya pada tahun 2012 yang dipengaruhi parameter cuaca seperti suhu udara rata-rata, tekanan udara, jumlah hari, kelembaban udara rata-rata dan kecepatan angin.

\section{TINJAUAN TEORI}

a. Curah Hujan

Presipitasi adalah peristiwa turunnya air ke permukaan bumi, yang bisa berupa hujan, hujan salju, kabut, embun dan hujan es. Di daerah tropis, termasuk Indonesia, yang memberikan sumbangan paling besar adalah hujan sehingga seringkali hujanlah yang dianggap sebagai 
presipitasi. Hujan berasal dari uap air di atmosfer, sehingga bentuk dan jumlahnya dipengaruhi oleh faktor klimatologi seperti angin, temperatur, dan tekanan atmosfer. Uap air tersebut akan naik ke atmosfer sehingga mendingin dan terjadi kondensasi menjadi butir butir air dan kristal kristal es yang akhirnya jatuh sebagai hujan.

Terjadinya hujan karena adanya perpindahan massa uap air ke tempat yang lebih tinggi sebagai respon adanya beda tekanan udara antara dua tempat yang berbeda ketinggiannya. $\mathrm{Di}$ tempat tersebut, karena akumulasi uap air pada suhu yang rendah maka terjadilah proses kondensasi, dan pada gilirannya massa uap air tersebut jatuh sebagai air hujan. Namun demikian, mekanisme berlangsungnya hujan melibatkan tiga faktor utama. Dengan kata lain, akan terjadi hujan apabila berlangsung tiga kejadian sebagai berikut 1)

1. Kenaikan massa uap air ke tempat yang lebih tinggi sampai saatnya atmosfer menjadi jenuh.

2. Terjadi kondensasi atas partikel-partikel uap air di atmosfer.

3. Partikel - partikel uap air tersebut bertambah besar sejalan dengan waktu untuk kemudian jatuh ke bumi dan permukaan laut (sebagai hujan) karena gravitasi.

Hujan sangat dipengaruhi oleh iklim dan keadaan topografi daerah,sehingga keadaanya sangat berbeda untuk masing -masing daerah ${ }^{2)}$.

Keberadaan atmosfer sangat penting dalam proses distribusi air keseluruhan permukaan bumi, karena kemampuannya dalam menampung dan mengangkut uap air. Siklus hidrologi tidak dapat berlangsung, jika atmosfer tidak dapat menampung dan mengakut uap air tersebut. Hujan yang berlebihan bisa menyebabkan banjir dan yang pastinya segala air yang ada di berbagai wadah tersebut akan mengalami penguapan atau evaporasi dengan bantuan matahari. Proses penguapan air dari tumbuh - tumbuhan dinamakan transpirasi. Kemudian uap air tersebut akan mengalami proses kondensasi atau pemadatan yang akhirnya menjadi awan. Awan - awan tersebut akan bergerak ke tempat yang berbeda dengan bantuan hembusan angin secara vertikal maupun horizontal. Gerakan angin vertikal ke atas menyebabkan awan bergumpal. Gerakan angin tersebut menyebabkan gumpalan angin semakin membesar dan saling bertindih. Akhirnya gumpalan awan berhasil mencapai atmosfer yang bersuhu lebih dingin. Disinilah butiran - butiran air dan es mulai terbentuk. Lama kelamaan angin tidak dapat lagi menopang berat awan dan akhirnya awan yang sudah berisi air ini mengalami prespitasi atau proses jatuhnya air.

\section{b. Suhu Udara}

Suhu udara adalah keadaan derajat panas atau dinginnya udara. Suhu biasanya diukur dalam skala celcius (C), Reamur (R), atau Fahrenheit (F). faktor-faktor yang mempengaruhi tinggi rendahnya suhu udara suatu daerah adalah lama penyinaran matahari, sudut pandang sinar matahari, sudut datang sinar matahari, relief permukaan bumi, jumlah awan, dan letak lintang.

Untuk menghitung suhu rata-rata suatu tempat di bumi dapat menggunakan rumus :

$\mathrm{T}_{\mathrm{x}}=\mathrm{T}_{\mathrm{o}}-0,6 \frac{\mathrm{h}}{100}$

Dengan : $T_{x}=$ suhu rata-rata pada $x ; T_{0}=$ suhu awal pada suatu tempat;

$\mathrm{h}=$ ketinggian pada suatu tempat;

Konstanta 0,6 dan 100 didapat dari vertikal gradient temperatur atau lapce rate, tiap kenaikan bertambah 100 meter, suhu udara berkurang (turun) rata-rata $0,6{ }^{\circ} \mathrm{C}$. Suhu rata-rata biasanya sangat dipengaruhi oleh sumber utama panas radiasi matahari. Suhu permukaan suatu benda akan meningkat atu menurun jika terjadi kontak langsung dengan radiasi matahari. Laju penguapan akan semakin besar jika suhu udara tinggi atau semakin panas, berarti jumlah air yang menguap juga semakin banyak. ${ }^{3)}$

\section{c. Tekanan Udara}

Udara yang mengembang menghasilkan tekanan udara yang lebih rendah, sedangkan udara yang berat menghasilkan tekanan yang lebih tinggi. Tekanan udara yang menunjukkan tenaga yang bekerja untuk menggerakkan massa udara dalam setiap satuan luas tertentu. Tekanan udara akan semakin rendah pada tempat yang semakin tinggi, tekanan uap air ditentukan oleh kerapatan uap air dan suhu.

Hubungan antara tekanan uap air, kerapatan uap air dan suhu dapat dinyatakan dengan persamaan :

$P_{A}=0,056 \rho_{v} R T$

Dengan: $\mathrm{P}_{\mathrm{A}} \quad=$ tekanan uap air $\left(\mathrm{N} / \mathrm{m}^{2}\right)$;

$\rho_{V} \quad=$ kerapatan uap air $\left(\mathrm{kg} / \mathrm{m}^{3}\right)$;

$\mathrm{R}=$ konstanta gas umum $\left(8,31 \times 10^{-3} \mathrm{~J} / \mathrm{mol}\right.$ $\left.{ }^{0} \mathrm{~K}\right) ; \mathrm{T}=\operatorname{suhu}\left({ }^{\mathrm{O}} \mathrm{K}\right)$

Penguapan yang terjadi semakin besar, apabila tekanan udaranya semakin rendah diatas permukaan air, tekanan udara dapat diukur dengan menggunakan barometer, nilai tekanan udara biasanya dinyatakan dalam milibar ${ }^{4)}$.

\section{d. Kecepatan Angin}

Jika pada suatu saat terjadi perbedaan tekanan udara pada arah medatar, maka akan terjadi gerakan perpindahan massa udra dari tempat dengan tekanan udara yang tinggi ke tempat dengan tekanan udsara yang rendah. Gerakan perpindahan massa udara pada arah mendatar tersebut disebut arus angin.

Perbedaan tekanan udara pada umumnya terjadi disebabkan perbedaan temperatur udara, 
yang pada permukaan bumi disebabkan adanya perbedaan pemanasan atau penerimaan panas diatas permukaan bumi.

Gerakan arus angin jarang sekali dapat berlangsung dalam keadaan rata atau halus, tetapi pada umunya terganggu oleh adanya turbulensi dalam berbagai bentuk dan ukuran yang berkembang dan saling mengganggu dengan arah dan gerakannnya. Dekat pada permukaan bumi turbulensi ini terutama sebagai akibat dari gesekan antara udara yang bergerak dengan permukaan bumi yang umumnya tidak rata yang dapat diakibatkan oleh faktor geografis atupun adanya bangunan - bangunan yang cukup tinggi.

Gerakan suatu massa udara pada permukaan yang mendatar ditentukan atau dipengaruhi oleh tiga macam gaya, ialah

1. Gaya Tekan atau gaya gradien tekanan udara. Merupakan gaya pendorong pada gerakan massa udara pada arah mendatar, tidak lain karena adanya gradien tekanan udara pada arah mendatar, yang arahnya dari tekanan tinggi ke tekanan rendah. Makin besar nilai perbedaan tekanan udara diantara kedua tempat tersebut makin besar pula kecepatan angin yang ditimbulkan. Besar dan kecilnya perbedaan tekanan udara antara dua tempat yang mendatar tersebut dinamakan gradien tekanan udara. Dengan adanya gradien tekanan udara tersebut akan timbul suatu gaya yang disebut sebagai gaya gradien tekanan udara atau disingkat gaya gradien.

2. Gaya Coriolli akibat perputaran bumi pada porosnya. Merupakan gaya pembelokan atau gaya penyimpangan, yang membelokan atau menyimpangkan gerakan arus angin dari arah gaya pendorongnya. Gaya corioli tersebut merupakan gaya semu yang timbul sebagai akibat dari perputaran bumi pada porosnya. Besarnya gaya corioli dapat dirumuskan debagai berikut :

$\mathrm{C}=2 \mathrm{~V} \omega \sin \mathrm{Q}$

Dengan: $C=$ Gaya corioli yang membelokan ; $\mathrm{V}=$ Kecepatan angin yang bersangkutan; $\omega=$ Kecepatan sudut bumi pada porosnya;

$\mathrm{Q}=$ Lintang tempat diman angin berada.

3. Gaya hambat akibat gesekan dengan sekitarnya. Merupakan gaya yang ditimbulkan oleh adanya gesekan antara massa udara yang bergerak dengan permukaan bumi atau udara lain disekitarnya. Baik yang ada diatasnya maupun yang ada dibawahnya.

\section{e. Kelembaban Udara}

Kelembaban udara adalah banyaknya uap air yang terkandung di udara pada suatu tempat yang dinyatakan dengan banyaknya gram uap air didalam $1 \mathrm{~m}^{3}$ udara ${ }^{5}$. Uap air adalah sumber dari semua bentuk kondensasi. Uap air dapat menyerap baik radiasi sinar matahari maupun radiasi bumi. Udara yang panas dapat menyimpan lebih banyak uap air dibandingkan dengan udara yang lebih dingin penguapan diatas lautan lebih besar dari pada diatas daratan, hal ini disebabkan tidak terbatasnya suplai air dipermukaan laut.

Suatu tempat yang mempunyai kelembaban relatif rendah, apabila udara dekat permukaan air adalah kering, sehingga penguapan yang akan terjadi akan lebih besar. Kelembaban udara terdiri dari dua macam, yaitu ${ }^{6}$ :

1. Kelembaban udara absolut adalah

Banyaknya uap air yang terdapat diudara pada suatu tempat, dinyatakan dengan banyaknya gram uap air dalam $1 \mathrm{~m}^{3}$ udara

2. Kelembaban udara relatif adalah

Perbandingan jumlah uap air dalam udara dengan jumlah air maksimum yang dapat dikandung oleh udara dalam suhu yang sama dan dinyatakan dalam persen (\%). Persamaan kelembaban udara dapat dinyatakan sebagai berikut:

$\mathrm{RH}=\frac{\mathrm{P}_{\mathrm{A}}}{\mathrm{P}_{\mathrm{S}}} \times 100 \%$

Dengan :

$\mathrm{RH} \quad=$ kelembaban relatif (\%);

$\mathrm{P}_{\mathrm{A}} \quad=$ tekanan uap air pada saat pengukuran $\left(\mathrm{N} / \mathrm{m}^{2}\right)$;

$\mathrm{PS}_{\mathrm{S}} \quad=$ tekanan uap air jenuh $\left(\mathrm{N} / \mathrm{m}^{2}\right)$

Kelembaban relatif merupakan parameter penting yang harus diperhatikan, sehingga harus diketahui cara mengukurnya. Secara umum pengukuran kelembaban relatif yang praktis digunakan lebih akurat menggunakan psychrometer (thermometer dari bola basah dan bola kering).

\section{f. Hari Hujan}

Hari Hujan adalah banyaknya jumlah hari yang terukur memiliki jumlah hujan tertentu atau akumulasi jumlah hari dalam sebulan yang tercatat ada hujan. Jumlah hari hujan biasanya diakumulasikan tiap 1 bulan.

\section{DATA DAN METODE}

\subsection{Data}

Data yang digunakan dalam kajian ini adalah data yang tercatat dalam format FKLIM 71 yang merupakan data iklim di Stasiun Meteorologi Pekanbaru yang dianggap mewakili pengukuran kondisi iklim di Kota Pekanbaru selama tahun 2012, yang terdiri atas data:

a. Jumlah Curah Bulanan

b. Suhu Udara Rata-rata

c. Tekanan Udara

d. Kelembaban Udara Rata-rata

e. Kecepatan Angin Rata-rata

f. Banyaknya Hari Hujan 
Dalam simulasi ini data-data yang diambil diatas dibatasi hanya untuk tahun 2012 dari parameter cuaca yang digunakan untuk memprediksi jumlah curah hujan selama tahun 2012. Data jumlah curah hujan tahun 2012 hasil observasi dianggap sebagai pembanding untuk verifikasi jumlah curah hujan bulanan hasil model output simulasi.

\subsection{Metode}

\subsubsection{Metode Regresi Linear berganda dan Koefisien Korelasi}

Metode prediksi regresi linier berganda ini dilakukan dengan cara membentuk persamaan regresi yang digunakan untuk melakukan simulasi prediksi jumlah curah $h$ ujan bulanan menggunakan lebih dari dari satu variabel independen. Kemudian hasil prediksi jumlah curah hujan bulanan menggunakan input data parameter cuaca yaitu suhu udara, tekanan udara, kelembaban udara, jumlah hari hujan dan kecepatan angin ini dibandingkan dengan data observasi.. Adapun persamaan umum metode ini adalah sebagai berikut ${ }^{7)}$

$$
Y=B_{O}+B_{1} X_{1}+B_{2} X_{2}+\ldots . .+B_{k} X_{K}(5)
$$

Dengan:

$\mathrm{B}_{\mathrm{O}}=$ konstanta;

$\mathrm{B}=$ koefisien variabel $\mathrm{X}_{1}, \mathrm{X}_{2}, \ldots, \mathrm{X}_{\mathrm{k}}$;

$Y=$ variabel yang diduga (variabel dependen);

$\mathrm{X} \mathrm{i}=$ variabel penduga (variabel independen).

Untuk analisis dengan metode regresi dibedakan dua jenis variabel ialah variabel bebas (independent) atau variabel prediktor dan variabel tidak bebas (dependent) atau variabel respon. Variabel bebas merupakan variabel yang dapat mempengaruhi varibel tidak bebas atau variabel yang dapat memprediksi harga variabel tidak bebas. Variabel ini dinyatakan dengan $\mathrm{X}_{1}, \mathrm{X}_{2}, \ldots$, $X_{k}$. Sedangkan variabel tidak bebas merupakan variabel yang terjadi karena variabel bebas atau variabel yang mencerminkan respon dari variabel bebas, dinyatakan dengan $Y^{8}$.

Dalam kajian ini memiliki 5 variabel bebas atau variabel penduga yaitu suhu udara, tekanan udara, kelembaban udara, jumlah hari hujan, dan kecepatan angin, dimana dalam persamaan regresi linear berganda untuk model prediksi yang valid sebaiknya digunakan lebih banyak variabel bebas, sedangkan variabel tidak bebas (dependent) atau variabel respon adalah jumlah curah hujan bulanan. Penulis sebelum melakukan simulasi prediksi jumlah curah hujan bulanan dengan input data parameter cuaca langkah awal yang dilakukan terlebih dahulu untuk menghindari munculnya multikoleniaritas dari variabel bebas $X_{1}, X_{2}, \ldots, X_{k}$ dengan melakukan langkah uji koefisien korelasi terlebih dahulu. Rumusan
Korelasi ${ }^{7)}$ :

$$
r(X, Y)=\frac{n \cdot \Sigma x y-\Sigma x \cdot \Sigma y}{\operatorname{Sqr}\left\{\left(n \cdot \Sigma x^{2}-(\Sigma x)^{2}\right)\left(n \cdot \Sigma y^{2}-(\Sigma y)^{2}\right)\right\}}
$$

Nilai $r$ adalah nilai yang menyatakan kuat tidaknya hubungan antara nilai $x$ dan nilai $y$, nilai $r$ ini berada diantara - 1 sampai dengan 1 atau dapat dinyatakan sebagai berikut:

$$
-1 \leq r(x, y) \leq 1
$$

artinya:

1. $r(x, y)=+1$, hubungan antara $x$ dan $y$ sempurna dan positif (mendekati +1 ), berarti hubungan keduanya sangat kuat dan bersamaan fase atau berbanding lurus.

2. $r(x, y)=-1$, hubungan antara $x$ dan $y$ sempurna dan negatif (mendekati -1), berarti hubungan sangat kuat dan berlawanan fase atau berbanding terbalik.

3. Apabila nilai $r(x, y) \geq+0,5$ atau $r(x, y) \leq-0,5$, berarti hubungan antara $x$ dan $y$ dianggap cukup kuat.

4. Apabila nilai $r(x, y)<+0,5$ atau nilai $r(x, y)>-$ 0,5 berarti hubungan antara $x$ dan $y$ dianggap lemah.

\subsubsection{Metode Validasi}

\section{a. Mean Absolut Error (MAE)}

Untuk keperluan evalusi dan untuk mengetahui besarnya penyimpangan yang terjadi antara nilai prediksi jumah curah hujan dibandingkan dengan nilai jumlah curah hujan aktualnya atau hasil observasi yang terjadi selama satu tahun. Dari nilai ini dapat dilakukan analisa apakah nilai prediksi jumlah curah hujan dengan predictor parameter cuaca di Pekanbaru bisa digunakan sebagai referensi untuk prakiraan jumlah curah hujan di lokasi lai yang memiliki nilai penyimpangan yang besar atau kecil ${ }^{9)}$.

MAE $=\frac{1}{n} \sum_{k=1}^{k=n}|Y k-O k|$

Dengan: $\mathrm{MAE}=$ Mean Absolut Error $(\mathrm{mm}), \mathrm{Yk}=$ Data prediksi jumlah curah hujan bulanan $(\mathrm{mm})$, Ok = Data jumlah curah hujan aktual hasil observasi $(\mathrm{mm}), \mathrm{k}=$ banyak data $=1,2,3, \ldots . \mathrm{n}$.

Perlu diketahui bahwa untuk validasi hasil prakiraan semakin besar nilai MAE, maka semakin jauh nilai data total hujan bulanan prakiraan terhadap jumlah curah hujan aktualnya dan semakin kecil nilai MAE maka semakin baik prediksi jumlah curah hujannya. Karena tingkat kesalahan yang dapat diminimalisir dapat meningkatkan tingkat akurasi prakiraan ${ }^{10)}$.

\section{b. Uji t Student}

Nilai curah hujan hasil prediksi yang nilai rata-ratanya dibandingkan dengan jumlah curah hujan hasil observasi digunakan untuk melakukan 
uji t. Uji distribusi student digunakan untuk mengetahui tingkat kesamaan nilai rata-rata $(\mu)$ terhadap masing-masing kelompok data sampel yang diuji perumusan hipotesis dalam statistika dalam uji $\mathrm{t}$ adalah sebagai berikut ${ }^{11)}$.

Ho: $\mu 1=\mu 2 \quad \mathrm{Ha}: \mu 1 \neq \mu 2 \mathrm{~s}$

Dengan : $\mathrm{Ho}=$ hipotesis nol; $\mathrm{Ha}=$ hipotesis alternatif; $\mu 1 \quad=$ nilai rata-rata dari data jumlah prediksi curah hujan; $\mu 2$ = nilai rata-rata dari data jumlah curah hujan aktualnya;

Nilai t hitung dapat dicari dengan menggunakan persamaan sebagai berikut:

$\mathrm{t}=\frac{X \text { mean } 1-X \operatorname{mean} 2}{\sqrt{\frac{\sum X \operatorname{mean} 1^{2}+\sum X \operatorname{mean} 2^{2}}{n(n-1)}}}$

Dengan:

thitung = nilai hitung dari distribusi $\mathrm{t}$,

Xmean1 = nilai rata-rata dari sampel yang pertama,
Xmean2 = nilai rata-rata dari sampel yang kedua, dan $\mathrm{n}=\mathrm{n} 1=\mathrm{n} 2=$ banyaknya anggota data sampel.

Selanjutnya dari hasil thitung yang diperoleh dibandingkan dengan ttabel yang didapat dari tabel distribusi $t$ dengan menggunakan tingkat keyakinan $\alpha=0,05$. derajad kebebasan untuk uji hipotesis ini adalah $n-1$. Ho diterima dengan ketentuan sebagai berikut:

- ttabel $\leq$ thitung $\leq+$ ttabel

\section{HASIL DAN PEMBAHASAN}

Untuk mengecek apakah kelompok variabel bebas yang berfungsi sebagai prediktor tidak terjadi multikoleniaritas dari masing-masing kelompok variabel data suhu udara, tekanan udara, kelembaban udara, kecepatan angin dan jumlah hari hujan dilakukan uji koefisien korelasi dapat dilihat pada tabel 1 .

Tabel 1. Nilai Koefisien Korelasi dari masing-masing variabel bebas

\begin{tabular}{lccccc}
\hline Variabel Bebas & $\begin{array}{c}\text { Suhu Udara } \\
(\mathrm{X} 1)\end{array}$ & $\begin{array}{c}\text { Tekanan } \\
\text { Udara }(\mathrm{X} 2)\end{array}$ & $\begin{array}{c}\text { Kelembaban } \\
\text { Udara }(\mathrm{X} 3)\end{array}$ & $\begin{array}{c}\text { Kecepatan } \\
\text { Angin }(\mathrm{X} 4)\end{array}$ & $\begin{array}{c}\text { Hari Hujan } \\
(\mathrm{X} 5)\end{array}$ \\
\hline Suhu Udara (X1) & 1.000 & -0.351 & -0.506 & 0.482 & -0.482 \\
Tekanan Udara (X2) & -0.351 & 1.000 & 0.403 & -0.419 & 0.045 \\
Kelembaban Udara & & & & & \\
(X3) & -0.506 & 0.403 & 1.000 & -0.236 & 0.689 \\
Kecepatan Angin (X4) & 0.482 & -0.419 & -0.236 & 1.000 & -0.213 \\
Hari Hujan (X5) & -0.482 & 0.045 & 0.689 & -0.213 & 1.000 \\
\hline
\end{tabular}

Tabel 2. Model persamaan regresi linear berganda dengan prediktor data parameter cuaca

\begin{tabular}{lrrrrrrrr}
\hline & Coefficients & Standard Error & t Stat & P-value & Lower 95\% & Upper 95\% & Lower 95.0\% & Upper 95.0\% \\
\hline Intercept & 46139.743 & 48090.823 & 0.959 & 0.374 & -71534.261 & 163813.747 & -71534.261 & 163813.747 \\
X Variable 1 & 26.793 & 52.688 & 0.509 & 0.629 & -102.129 & 155.716 & -102.129 & 155.716 \\
X Variable 2 & -47.322 & 47.606 & -0.994 & 0.359 & -163.811 & 69.166 & -163.811 & 69.166 \\
X Variable 3 & 9.047 & 7.382 & 1.225 & 0.266 & -9.017 & 27.110 & -9.017 & 27.110 \\
X Variable 4 & 29.172 & 42.659 & 0.684 & 0.520 & -75.210 & 133.555 & -75.210 & 133.555 \\
X Variable 5 & 12.125 & 6.673 & 1.817 & 0.119 & -4.204 & 28.454 & -4.204 & 28.454 \\
\hline
\end{tabular}

Dari tabel 2 dapat diketahui persamaan untuk menentukan prediksi jumlah curah hujan bulanan dengan masukkan data parameter cuaca didapatkan persamaan regresi linear berganda seperti berikut :

$$
\begin{aligned}
Y= & 46139.743+26.793 X_{1}-47.322 X_{2} \\
& +9.047 X_{3}+29.172 X_{4}+12.125 X_{5}
\end{aligned}
$$

Setelah didapatkan persaman diatas dimasukkan nilai parameter cuaca seperti suhu udara, tekanan udara, kelembaban udara, kecepatan angin dan banyaknya hari hujan yang ada pada tahun 2012 didapatkan nilai hubungan antara jumlah curah hujan hasil prediksi menggunakan persamaan regresi linear berganda dengan jumlah curah hujan aktualnya seperti yang terdapat dalam grafik 1 sebagai berikut 


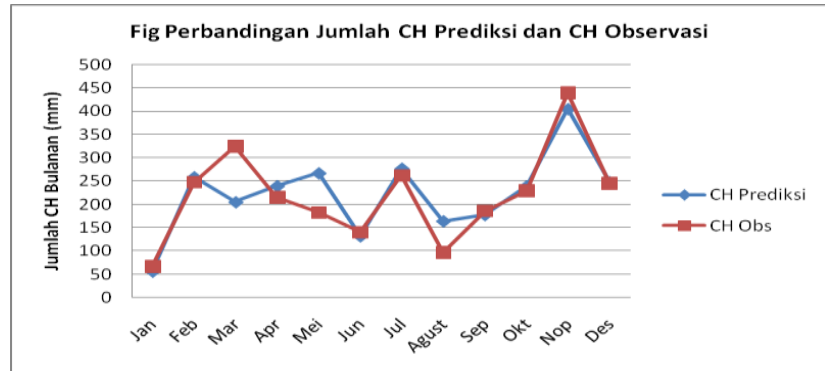

Grafik. 1 Perbandingan Jumlah Curah hujan prediksi dan Curah hujan aktualnya

Dari grafik 1 di atas diketahui bahwa jika jumlah curah hujan hasil observasi mengalami kenaikan yang sebanding dan jumlah curah hujan hasil prediksi juga mengalami kenaikan terjadi kenaikan yang sebanding terjadi pada bulan Januari- Februari, Juni - Juli, dan September Oktober - Nopember 2012. Untuk data jumlah curah hujan prediksi dan jumlah curah hujan observasinya terjadi pada bulan Mei - Juni, Agustus - September, dan Nopember - Desember 2012. Maka dari hasil analisa grafik diatas dapat dikatakan bahwa prediksi tersebut mendekati jumlah curah hujan bulanan yang sebenarnya dan hasil prediksi tersebut adalah cukup baik.

Dari hasil perhitungan nilai Mean Absolute Error dari dua sampel data yang dihitung yaitu nilai jumlah curah hujan prediksi dan nilai jumlah curah hujan bulanan aktualnya didapatkan nilai MAE sebesar $32.93 \mathrm{~mm}$. Artinya dengan jumlah curah hujan hasil prediksi dengan model persamaan regresi linear berganda input data parameter cuaca apabila dibandingkan dengan jumlah curah hujan aktualnya terjadi penyimpangan jumlah curah hujan bulannya sekitar $32.93 \mathrm{~mm}$. Dari analisa grafik 1, hasil prediksi jumlah hujan bulanan secara umum kenaikan dan penurunannya selaras dengan data jumlah curah hujan aktualnya, namun pada bulan-bulan tertentu seperti bulan Maret, Mei dan Agustus 2012 kerjadi penyimpangan jumlah curah hujan yang cukup besar. Anomali jumlah curah hujan bulanan ini dimungkinkan terjadi akibat faktor cuaca dan iklim seperti faktor global, regional dan lokal yang berpengaruh langusng terhadap pola keseimbangan cuaca di wilayah Kota Pekanbaru.

Dari hasil uji $\mathrm{t}$ student yang bertujuan untuk mencari kesamaan nilai rata-rata dari variabel yang diuji yaitu data jumlah curah hujan prediksi menggunakan model regresi linear berganda dengan input data parameter cuaca dengan nilai jumlah curah hujan aktualnya tahun 2012 mempunyai t hitung 1.595. Dari nilai t tabel didapatkan nilai 1.650 dengan tingkat signifikansi sebesar $5 \%$, karena nilai thitung $\leq$ ttabel sehingga Hipotesis nolnya diterima artinya nilai rata-rata dari masing-masing kelompok sampel data yang diuji terbukti memiliki tingkat kesamaan.

\section{KESIMPULAN}

Berdasarkan dari uraian yang telah dipaparkan oleh penulis tersebut di atas, maka dapat ditarik beberapa kesimpulan sebagai berikut:

1. Prediksi jumlah curah hujan bulanan tahun 2012 di Kota Pekanbaru dengan menggunakan data parameter cuaca sepert suhu udara, tekanan udara, kelembaban udara, kecepatan angin dan jumlah hari hujan menunjukan nilai prediksi yang cukup baik digunakan apabila kondisinya normal tidak ada anomali cuaca dan iklim baik dalam skala global, regional dan faktor lokal.

2. Prediksi total hujan bulanan menggunakan variabel bebas atau prediktor suhu udara, tekanan udara, kelembaban udara, kecepatan angin dan jumlah hari hujan sekaligus menggunakan persamaan regresi linier berganda menghasilkan model output yang relatif lebih baik dengan nilai penyimpangan 32,93 $\mathrm{mm}$ apabila dibandingkan dengan jumlah curah hujan bulanan aktualnya. Dari hasil uji t student terbukti dua kelompok data sampel yang diuji Hipotesis nol nya terbukti diterima yang artinya nilai rata-rata dari masing-masing data mempunyai nilai kesamaan.

\section{DAFTAR PUSTAKA}

Asdak, C., 2002. Hidrologi dan Pengelolaan Daerah Aliran Sungai. Gajah Mada University Press. Yogyakarta.

Handajani, N. 2005., Analisa distribusi Curah Hujan dengan Kala Ulang Tertentu, Jurnal Rekayasa Perencanaan, Vol 1. No.3, Juni 2006, Hal 46-57

Lakitan, B. (2002), Dasar - Dasar Klimatologi, Jakarta : PT. Raja Grafindo Persada

Wisnusubroto, T., 1986, Asas-Asas Meteorologi. Jakarta.

Regariana, C.M., 2005. Atmosfer (Iklim dan Cuaca). Jakarta. 

Wirjohamidjojo, S. \& Y.S.Swarinoto. (2007).
Praktek Jakarta: Badan Meteorologi dan Geofisika

Usman, H. \& Akbar, R.P.S. 2000. Pengantar Statistik. Jakarta: Penerbit Bumi Aksara.

Sudjana. (1995). Metoda Statistika. Bandung: Penerbit Tarsito.

Wilks, D.S. (1995). Statistical Methods in the Atmospheric Science, San Diego: Academic Press.
Soetamto \& Maria, U.A. 2010. Modul Pelatihan Peningkatan Akurasi Prakiraan Musim. Jakarta:BMKG.

Trihendradi, C. (2005). Step By Step SPSS 13, Analisis Data Statistik. Yogyakarta: Penerbit ANDI 